\title{
Reverse transcription-polymerase chain reaction (RT-PCR) based detection and economic impact of foot-and-mouth disease in District Faisalabad, Pakistan during the year 2015
}

\author{
W. Ali ${ }^{*}$, M. Habib, R.S.A. Khan ${ }^{1}$, M.A. Zia, I.U. Khan ${ }^{1}$, U. Saliha ${ }^{2}$, M. Farooq ${ }^{1}$, \\ M.S. Shah ${ }^{1}$, H.M. Muzammil ${ }^{1}$
}

${ }^{1}$ Department of Biological Sciences, Nuclear Institute for Agriculture and Biology (NIAB), Faisalabad, affiliated with Pakistan Institute of Engineering and Applied Sciences (PIEAS), Islamabad, ${ }^{2}$ Civil Veterinary Hospital, Faisalabad, Pakistan.

*Corresponding Author: drwaqaasali@gmail.com

(Received November 29, 2016; Accepted January 22, 2017)

\begin{abstract}
The aim of this study was to evaluate the economic impact of the disease by using milk production records and to determine the serotypes circulating in the region during 2015. Sampling was done from different outbreaks initially on the basis of clinical signs and later reverse transcriptase-polymerase chain reaction (RT-PCR) was employed for the conformation of FMDV genome. Out of total 88 samples, 73 were found positive which were then serotyped into type $\mathrm{O}(\mathrm{n}=44)$, Asia1 $(\mathrm{n}=18)$ and $\mathrm{A}(\mathrm{n}=06)$. The economic impact was analyzed by recording milk loss at four affected farms. Their average milk yield was observed 9.2 liters before the onset of disease that decreased dramatically after the disease. Milk loss of 225 and 195 liters was recorded for buffalo and cattle respectively, during 70 days of the study period.
\end{abstract}

Keywords: FMD, RT real time PCR, economic impact, milk yield, type O, type Asia1, type A Available online at http://www.vetmedmosul.org/ijvs

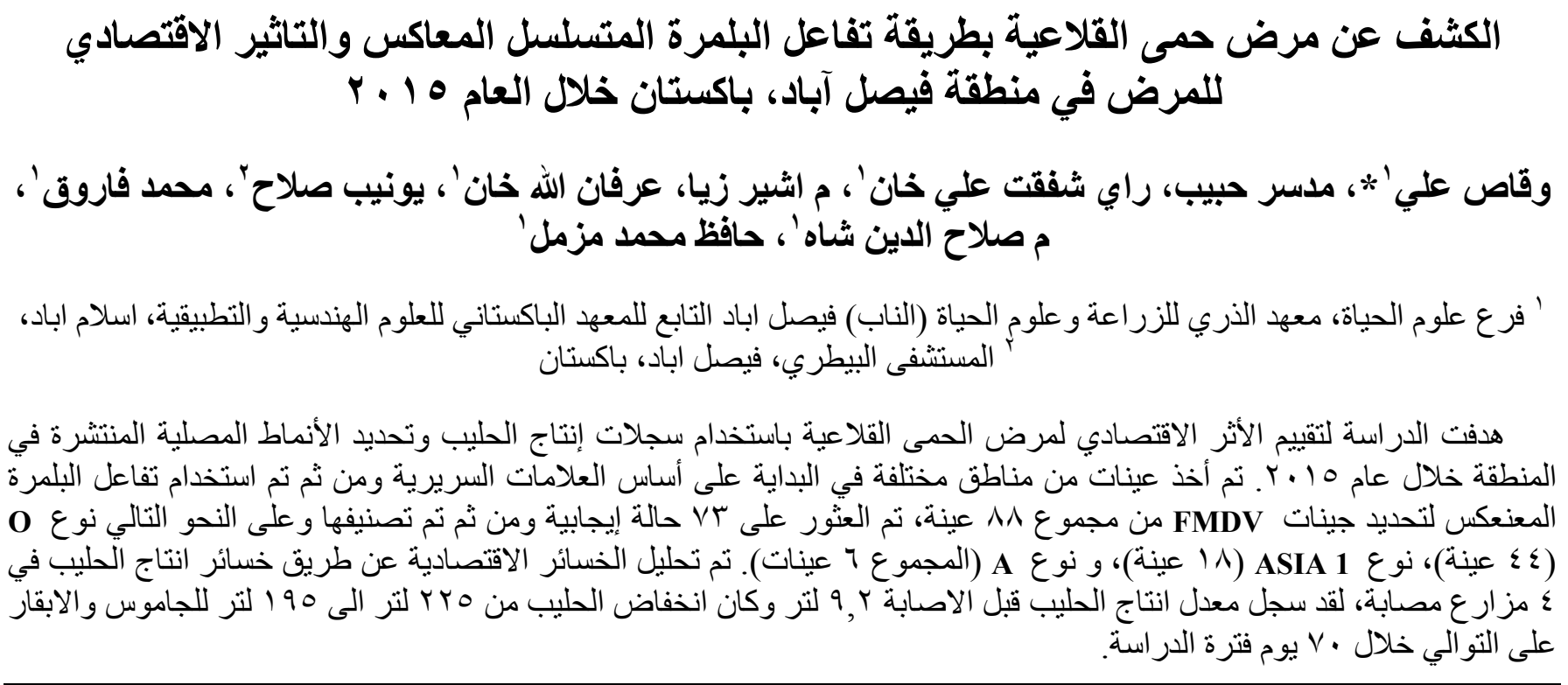

\section{Introduction}

Foot and mouth disease (FMD) is a disease of clovenhoofed animals and causes severe socioeconomic losses by infecting domestic animals, i.e. buffalo, cattle, goats, sheep and pigs. The causative agent of this notorious disease belongs to genus Aphthovirus, family Picornaviridae and known as FMD virus (FMDV). The virus lack envelope, 
has 8.3 kilobases, +ve sense RNA genome (1). Seven serotypes $(\mathrm{O}, \mathrm{C}, \mathrm{A}$, Asia1 and SAT1, SAT2, SAT 3, are known for this virus (2). Within each serotype, multiple subtypes are found which sometimes do not protect against the same serotype. The distribution of the FMDV serotype is not uniform, generally, serotype $\mathrm{O}$ and $\mathrm{A}$ are widely distributed throughout the globe as compared to other serotypes. Serotype Asia 1 is limited to the Asia, while SAT 1, SAT 2, SAT 3 are found normally in Sub-Saharan Africa and serotype $\mathrm{C}$ has not been reported since 2005 anywhere (3). In Pakistan, three serotypes A, O and Asia 1 are prevalent (4) and occurrence of $\mathrm{O}$ is more as compared to other serotypes (5-9). Signs and symptoms include lesions on foot, mouth, udder etc. as shown in the fig. 1 Pakistan is one of the top (42 million tonnes) milk producing countries in the world and $95 \%$ of milk comes from small peri-urban and rulers livestock farmers $(10,11)$. Main milk producing animals are buffalo and cattle contributing $62 \%$ and $34 \%$ respectively. Production of milk from cows increased (from 7.42 to 9.4) million tonnes. 35 million peoples are involved in livestock and obtain 30$40 \%$ of their income $(9,12-14)$. The current study focuses on effective diagnosis and calculation of economic loss due to a decrease in milk production. Very few studies on economics importance of this disease are present, although the disease is very old in its origin (15). Studies revealed $20 \%$ to $24 \%$ loss in milk production in cattle and $19 \%$ in sheep (15). Local cattle breed showed $35 \%$, cross breed $17 \%$ and Holstein Friesian $37 \%$ decrease in milk production (16). FMD caused $19 \%$ milk loss in turkey (17) and $25 \%$ in the UK (18). Post-FMDV 216 to 370 US dollars loss was recorded in a study of 62 Cambodian farmers (19). FMD caused $7.6 \%$ to $10 \%$ burden on the income of poor livestock farmers. This interview-based study revealed that $84 \%$ of the farmers agreed to pay 1.3 US dollars/animal to protect their animals for six months (20). In Pakistan, if we invest one US dollar on vaccination we can save milk loss of 5.7 US dollars (21).

\section{Materials and methods}

\section{Sample collection}

Total 41 outbreaks were recorded during this study from district Faisalabad and 88 samples were collected in autoclaved plastic vials having a $15 \mathrm{ml}$ capacity filled with $8-10 \mathrm{ml}$ glycerolized buffer saline. Detail of the samples collected is given in the table 2. Samples were brought to the lab by keeping in the icebox and stored at $-70 \mathrm{C}$ for further processing.

\section{RNA extraction}

RNA extraction was carried out with the help of PavorPrep Viral Nucleic Acid Extraction Kit (Favorgen,
China) according to Manufacturer's protocol. Briefly, $570 \mu \mathrm{l}$ of lysis buffer is added to $150 \mu \mathrm{l}$ of sample (serum/epithelial tissue supernatant) and incubated for 10 minutes at room temperature. Then ethanol $(750 \mu \mathrm{l})$ precipitation is carried out after which RNA is transferred to silica based column and centrifuged at $8000 \mathrm{~g}$ for $1 \mathrm{~min}$. One washing with $500 \mu \mathrm{l}$ of wash bufferl and two with wash buffer 2 was carried out on $8000 \mathrm{~g}$ for $1 \mathrm{~min}$ after every washing. After washing RNA was eluted using $35 \mu 1$ elution buffer in a centrifuge tube for $2 \mathrm{~min}$ at $8000 \mathrm{~g}$ and stored at $-70^{\circ} \mathrm{C}$ until further use.

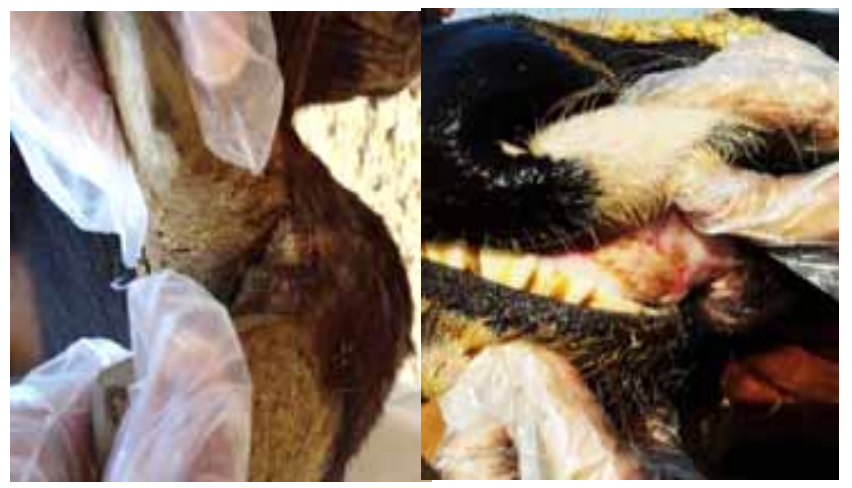

Figure 1: Showing lesions on the hoof and mouth epithelium during a FMD outbreak in District Faisalabad.

\section{Complementary DNA Synthesis (cDNA)}

Fermentas Revert Aid First Strand cDNA Kit was used for cDNA preparation. Briefly, $5 \mu$ l RNA template was incubated with $1 \mu \mathrm{l}$ of random hexamer primer $(0.2 \mathrm{ug} / \mu \mathrm{l})$ and $6 \mu 1$ nuclease-free water at $65^{\circ} \mathrm{C}$ for 5 minutes than ice chilled and short spin. After that, $5 \mathrm{X}$ reaction buffer $4 \mu 1$, Ribolock $1 \mu$ l, dNTPs $(10 \mathrm{mM}) 2 \mu$, revert Aid (reverse transcriptase) $1 \mu \mathrm{l}$ were added into it and incubated in PCR machine with $25^{\circ} \mathrm{C}$ for 5 minutes, $42^{\circ} \mathrm{C}$ for 60 minutes and $70^{\circ} \mathrm{C}$ for minutes to terminate the reaction. After synthesis, cDNA was stored at $-20 \mathrm{C}$ for future use.

\section{PCR}

cDNA was subjected to the general FMD detection primers $(1 \mathrm{~F}, 1 \mathrm{R})$ as well as typing primers using following procedure: $1 \mu \mathrm{l}$ cDNA, $1 \mu \mathrm{l}$ Forward primer $(1 \mathrm{~F})(10$ $\mathrm{pM} / \mu \mathrm{l}), 1 \mu \mathrm{l}$ Reverse primer (1R) $(10 \mathrm{pM} / \mu \mathrm{l}), 5 \mu 1$ 10X Taq polymerase buffer, $5 \mu 1 \mathrm{MgCl} 2(25 \mathrm{mM}), 1 \mu 14 \mathrm{X}$ dNTP mix (10 $\mathrm{mM}$ each), $0.2 \mu \mathrm{l}$ Taq plus DNA polymerase $(5 \mathrm{U} / \mu \mathrm{l})$ and $35 \mu \mathrm{l}$ Double Deionized water (ddH2O) in a micro PCR tube. Thermal cycling conditions were $94^{\circ} \mathrm{C}$ for 10 min, followed by 35 cycles at $95^{\circ} \mathrm{C}$ for $45 \mathrm{~s}, 55^{\circ} \mathrm{C}$ for $45 \mathrm{~s}$ and $72^{\circ} \mathrm{C}$ for $45 \mathrm{~s}$. A final extension was carried out at $72^{\circ}$ $\mathrm{C}$ for $10 \mathrm{~min}$. 
Table 1: The oligonucleotide primers used for RT-PCR diagnosis and serotyping

\begin{tabular}{llccc}
\hline Primer * & Sequence $5^{\prime} \rightarrow 3^{\prime}$ & Location & Sense & Specificity \\
\hline 1F & GCCTGGTCTTCCAGGTCT & 5'UTR & Forward & All types \\
1R & CCAGTCCCCTTCTCAGATC & 5’UTR & Reverse & All types \\
P33 & AGCTTGTACCAGGGTTTGGC & 2B & Reverse & All types \\
P38 & GCTGCCTACCTCCTTCAA & 1D & Forward & Type O \\
P74 & GACACCACTCAGGACCGCCG & 1D & Forward & Type O \\
P75 & GACACCACCCAGGACCGCCG & 1D & Forward & Type O \\
P90 & GTCATTGACCTCATGCAGACTCAC & 1D & Forward & Type A \\
P91 & GTCATTGACCTCATGCAAACCCAC & 1D & Forward & Type A \\
P92 & GTCATTGACCTTATGCAGACTCAC & 1D & Forward & Type A \\
P76 & GACACCACACAAGACCGCCG & 1D & Forward & Type Asia1 \\
P77 & GACACGACTCAGAACCGCCG & 1D & Forward & Type Asia1 \\
P87 & GTCATTGACCTCATGCAGACCCAC & 1D & Forward & Type Asia1 \\
P88 & GTTATTGACCTCATGCAGACCCAC & 1D & Forward & Type Asia1 \\
P89 & GTCATTGACCTCATGCACACCCAC & 1D & Forward & Type Asia1 \\
\hline
\end{tabular}

* Primers were adapted from previous studies $(22,23)$.

\section{Economic study}

Milk production data were collected from 4 farms (Total no. of the animals were 75) at different FMD outbreak locations. Data of 22 clinically affected animals (10 buffalos, 12 cattle) was noted for 70 days by interview and follow up. The diagnosis was done primarily based on clinical signs that were later confirmed by RT-PCR. Data was collected in the form of a questionnaire and visit of the location. The questionnaire consists of two parts; first deal with the name, address and no. of animals at the farm while the second one deals with the milk production data of the animals. The focus was affected animals and their data collection by follow-up. The measurement of milk was done in litres usually used by the farmers to sell their milk. Milk price varies with season and during this study period; it was kept according to the Faisalabad market, i.e. 0.4 USD for cattle and 0.5 USD for buffalo per litre milk for economic loss calculations.

\section{Results}

Consensus primer pair $1 \mathrm{~F}$ and $1 \mathrm{R}$ was used for the detection of the FMDV while remaining primers mentioned in the table No. 1 were used for the detection of serotypes prevalent in Pakistan viz. Type A, O, Asia 1. 88 samples were subjected to these primers collected from different outbreak regions of District Faisalabad. Six samples were found positive for serotype A, 18 for serotype Asia 1 and 44 for serotype $\mathrm{O}$. Bands of $328 \mathrm{bp}$ with consensus primer pair and of 292, 432 and 702 bp (fig. 2) for serotype O, Asial and A respectively with typing primers was found when electrophoresed by $1.5 \%$ agarose gel (Invitrogen, Carlsbad, USA), prepared in $1 \times$ Tris-borate-EDTA buffer and stained with $0.5 \mathrm{~g} / \mathrm{ml}$ ethidium bromide The amplification products were visualized using a transilluminator at $302 \mathrm{~nm}$.

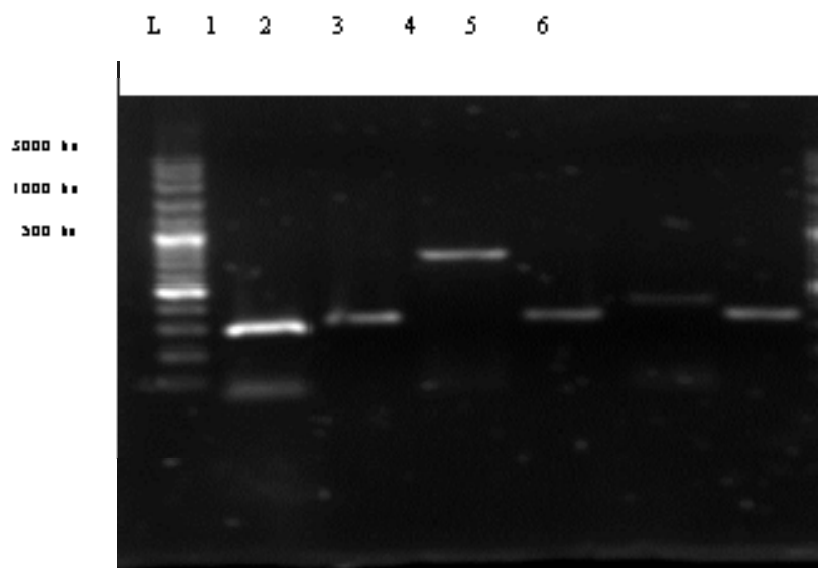

Figure 2: Lane 2, 4 and 6 shows the PCR product (328 bp) with consensus primer while lane 1, 3, and 5 shows the PCR products of type Asial (292 bp), type A (732 bp) and type $\mathrm{O}(402 \mathrm{bp}$ ) respectively with type specific primers.

\section{Economic study}

Not all questionnaire data is presented there only milk production loss is shown in Table 3 before and after the outbreak of FMD. Vaccination was absent in the majority of outbreaks and was irregular in some. Out of total 75 animals, 22 were found positive for FMD by laboratory diagnosis.

One of the main signs of FMD is a sudden drop in milk production. In this study, data of 22 lactating animals were recorded for 70 days by follow-up. Buffaloes show more decline and slow recovery in average milk production (Fig. 
4) as compared to cattle which shows a rapid decline, but quick recovery (Fig. 3). In general, both graphs depict abrupt decrease in milk production at day 5-7 after the FMD outbreak and gradual recovery takes place in 65-70 days (Fig. 5). Predicted value was calculated as the mean value of production at pre-FMD (day 0) and day 70 which showed a linear trend. Total loss of 225 litres $(51 \%$ of the predicted value) per lactating buffalo and 195 litres (31\% of the predicted value) per lactating cattle was recorded during 70 days of this study period. Total loss of 2061 USD (per litre price of ilk was kept 0.4 and 0.5 USD per litre for cattle and buffalo milk respectively) was recorded in 22 affected animals. We assumed expense of good quality vaccination is equal to $450 \mathrm{USD}$ (3 USD/Dose) for all 4 farms (75 animals) annually (the vaccination rate was keptr). Milk production twice a year).

The ratio between predicted milk loss and vaccination was 4.58 that means that 1 USD spent on vaccination could save 4.58 USD of milk loss.

Table 2: FMDV outbreak locations and results of Faisalabad district

\begin{tabular}{|c|c|c|c|c|c|c|}
\hline \multirow{2}{*}{$\begin{array}{l}\text { Administrative } \\
\text { regions }\end{array}$} & \multirow{2}{*}{$\begin{array}{c}\text { No. of } \\
\text { outbreaks }\end{array}$} & \multirow{2}{*}{$\begin{array}{l}\text { No. of } \\
\text { samples }\end{array}$} & \multirow{2}{*}{$\begin{array}{l}\text { FMDV } \\
\text { detected }\end{array}$} & \multicolumn{3}{|c|}{ FMDV typed } \\
\hline & & & & A & Asial & $\mathrm{O}$ \\
\hline Chak Jhumra & 06 & 19 & 17 & - & - & 07 \\
\hline Jaranwala & 05 & 07 & 05 & 02 & - & 05 \\
\hline Sadhar & 18 & 40 & 38 & 03 & 13 & 22 \\
\hline Sumandri & 03 & 09 & 08 & - & 03 & 08 \\
\hline Tandlianwala & 09 & 13 & 05 & 1 & 02 & 02 \\
\hline Total & 41 & 88 & 73 & $06(12 \%)$ & $18(25 \%)$ & $44(60 \%)$ \\
\hline
\end{tabular}

Table 3: Milk production of buffalos and cows during FMD outbreak

\begin{tabular}{lcccccccccccc}
\hline & \multirow{2}{*}{ Pre-FMDV } & Day & Day & Day & Day & Day & Day & Day & Day & Day & Day & Day \\
& & 1 & 3 & 5 & 7 & 10 & 15 & 22 & 30 & 40 & 55 & 70 \\
\hline Average & 9.2 & 6.6 & 4.16 & 2.83 & 2.6 & 3.0 & 3.48 & 3.94 & 4.07 & 4.69 & 5.46 & 6.25 \\
Standard deviation & 3.37 & 2.34 & 1.89 & 2.84 & 2.76 & 3.01 & 2.83 & 3.29 & 3.82 & 3.44 & 4.36 & 4.77 \\
\hline
\end{tabular}

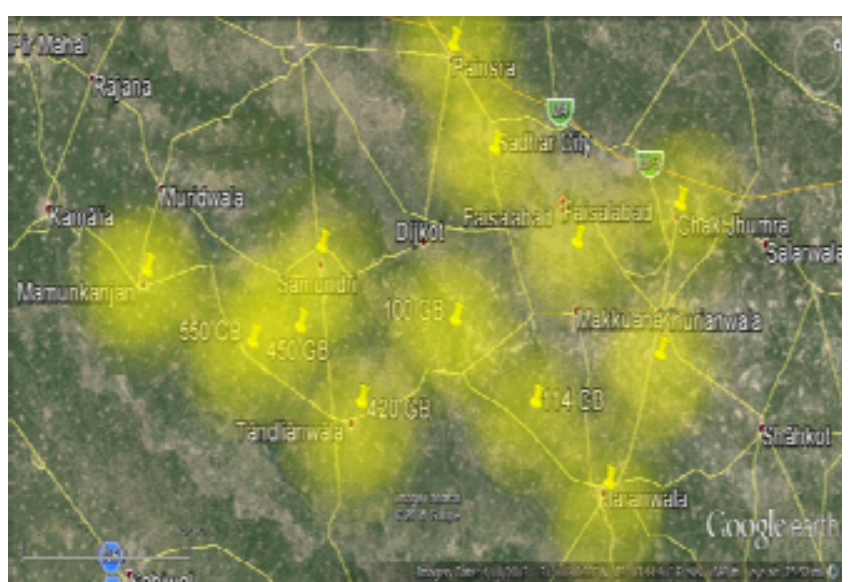

Figure 4: Map depicts outbreak zones of $10 \mathrm{Km}$ radius that were generated using Google earth software.

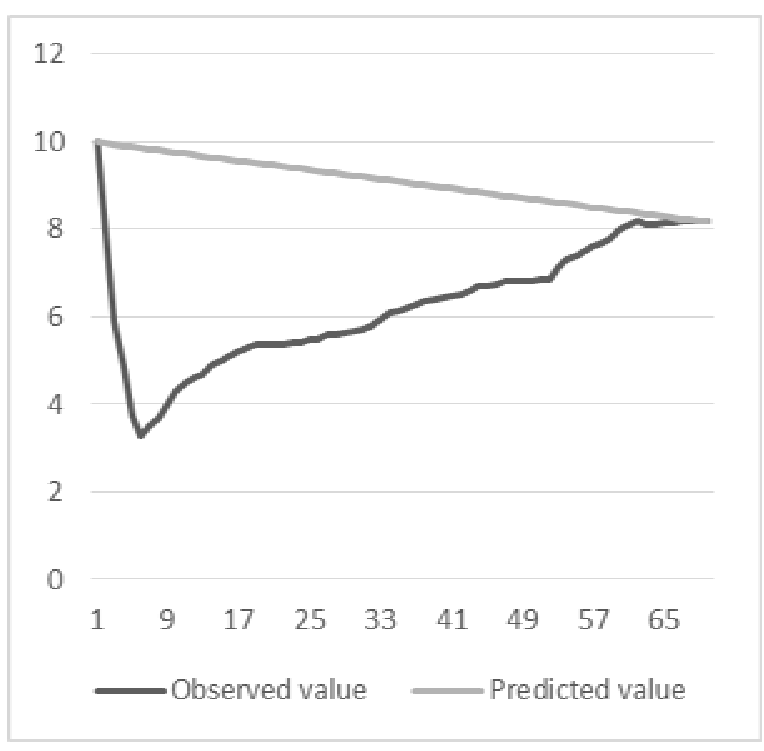

Figure 5: Observed and predicted data of 12 cattle after and before FMD onset. 


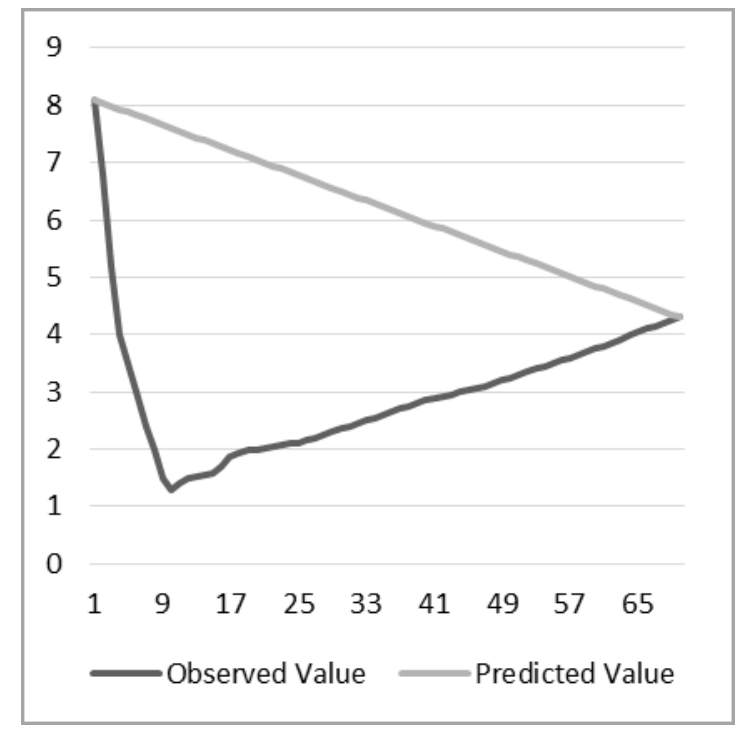

Figure 6: Observed and predicted data of 10 buffaloes after and before FMD onset.

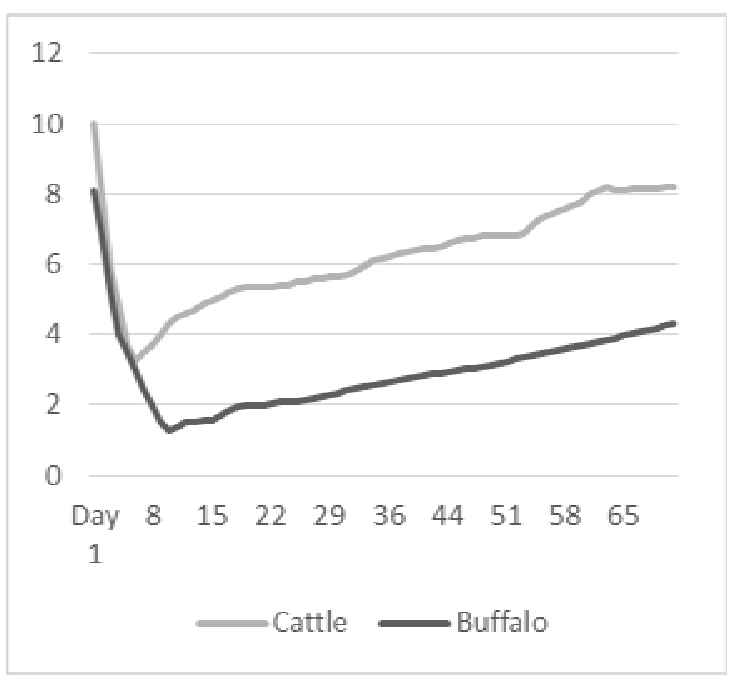

Figure 7: Trend of Average Milk production of studied animals.

\section{Discussion}

Out of total 88 cases detected positive for FMD based on clinical signs in the field, 73 was found positive in the laboratory. This indicates an accurate clinical diagnosis by field veterinarians in $83 \%$ cases, which shows sufficient skills of field staff of Livestock Department of District, Faisalabad. This also reveals that signs are so prominent/severe in most of the cases to facilitate diagnosis. Serotype $\mathrm{O}$ was found most frequently $(60 \%)$ for the outbreaks studied, followed by serotype Asia 1 (25\%) and then serotype A (12\%). Five samples that were found positive with consensus primers were not typed by the typing primers. This shows that there is a need for the development of regional typing primers as the virus differ from region to region and conserved portion of the virus genome in one geographical setting may be not so for the other one. Different parts of the world have developed their own consensus as well as typing primers (22). Buffer zones for FMD ring vaccination are kept of 5-10 km radius (23) because FMDV spread is predicted to cover a distance of $10 \mathrm{~km}(24)$. This finding is used to predict the zones of 10 $\mathrm{km}$ radius in Faisalabad district that illustrate that zones are intermingling with one another and it is very difficult to distinguish their boundaries indicating that almost whole study area is in the reach of FMDV because of these reported outbreaks. In this economic loss study, only the milk loss was considered. Other losses due to FMD, such as weight loss, mortality in young calves, abortions, etc. were not included in this study. The study of economic losses due to these can emphasise more on the need of need of regular vaccination in the country. However, only milk production losses indicate that if one USD is spent on vaccination, it can save 4.58 USD of milk loss.

\section{Acknowledgment}

We want to acknowledge Higher Education Commission (HEC), Islamabad, Pakistan and International Atomic Energy Agency (IAEA) for the provision of funding for this study. The author is thankful to Dr. Sana ullah Sajid for his help in data collection.

\section{References}

1. Rueckert RR, Wimmer E. Systematic nomenclature of picornavirus proteins. J Virol.1984;50:957.

2. Brooksby J. The virus of foot-and-mouth disease. Adv Virus Res. 1958;5:1-37.

3. Sumption K, Rweyemamu M, Wint W. Incidence and distribution of foot and mouth disease in Asia, Africa and South America; combining expert opinion, official disease information and livestock pop $\mu$ lations to assist risk assessment. Transbou Emerg Dise. 2008;55:5-13.

4. Rauf A, Khan N, Ahmed M. Typographical study of foot-and-mouth disease virus in Pakistan. Pakistan Vet J. 1981.

5. Yasin S, Huq M. Foot-and-mouth disease in Pakistan. Bulletin de l'Office International des Epizootics. 1960;54:378-383.

6. Khan FM. Participatory appraisal and scanning surveillance based contagious diseases risk profile of district Rahim Yar Khan (Pakistan). Pak Vet J. 2010;30:198-202.

7. Saeed A, Khan QM, Waheed U, Arshad M, Asif M, Farooq M. RTPCR evaluation for identification and sequence analysis of foot-andmouth disease serotype O from 2006 to 2007 in Punjab, Pakistan. Comp Immunol Microbiol Infect Dis. 2011;34:95-101.

8. Jamal SM, Ahmed S, Hussain M, Ali Q. Status of foot-and-mouth disease in Pakistan. Arch Virol. 2010;155:1487-1491.

9. Jamal SM, Ferrari G, Ahmed S, Normann P, Curry S, Belsham GJ. Evolutionary analysis of serotype A foot-and-mouth disease viruses circulating in Pakistan and Afghanistan during 2002-2009. J Gen Virol. 2011:vir. 0.035626-035620. 
10. FAO. Analysis of Milk Marketing Chain. In: Zia U. (ed.), Islamabad, Pakistan. 2006a.

11. FAO. Livestock's Long Shadow Steinfield, HP Gerber, T Wassenaar, V Castel, M Rosales, Haan C.(eds), Rome, Italy. 2006b.

12. Klein J, Hussain M, Ahmad M, Afzal M, d Alexandersen S. Epidemiology of foot-and-mouth disease in Landhi Dairy Colony, Pakistan, the world largest Buffalo colony. Virol J. 2008;5:53.

13. Jamal SM, Ferrari G, Ahmed S, Normann P, Belsham GJ. Genetic diversity of foot-and-mouth disease virus serotype $\mathrm{O}$ in Pakistan and Afghanistan, 1997-2009. Infect Genet Evol. 2011;11:1229-1238.

14. Jamal SM, Ferrari G, Ahmed S, Normann P, Belsham, GJ. Molecular characterization of serotype Asia-1 foot-and-mouth disease viruses in Pakistan and Afghanistan; emergence of a new genetic Group and evidence for a novel recombinant virus. Infect Genet Evol. 2011;11:2049-2062.

15. Nazlioglu M, Orun H. Researches on epidemiology, control and economics of FMD in Turkey. FMD Research Institute, Ongun Brothers Press, Ankara. 1969.

16. Adibes M, Gundogan M, Evgin N, Bacak N, Erginoz C, Taylor N, Evci A, Erdogan T, Cavusoglu S, Demirbas H. Detailed investigations, using farmer interview, to assess the losses caused by FMD outbreaks in Turkey. FMD Research Institute, Ankara. 1998.

17. Tufan M. An evaluation of the monitoring and control of foot and mouth disease in Turkey. Unpublished paper, University of Reading, United Kingdom. 1993.

18. Power A, Harris SA. Cost benefit evalution of alternative control policie for bfoot and mouth disease in great britain. J Agric $\mu$ l Econo. 1973;24:573-600.
19. Young J, Suon S, Andrews C, Henry L, Windsor P. Assessment of financial impact of foot and mouth disease on smallholder cattle farmers in Southern Cambodia. Transbo Emerg Dis. 2013;60:166-174.

20. Shankar B, Morzaria S, Fiorucci A, Hak M. Animal disease and livestock-keeper livelihoods in Southern Cambodia. Intern Develo Plann Rev. 2012;34:39-63.

21. Ferrari G, Tasciotti L, Khan E, Kiani A. Foot-and-Mouth Disease and Its Effect on Milk Yield: An Economic Analysis on Livestock Holders in Pakistan. Transbou and Emerg Dis. 2013;61:e52-e59.

22. Vangrysperre W, De Clercq K. Rapid and sensitive polymerase chain reaction based detection and typing of foot-and-mouth disease virus in clinical samples and cell culture isolates, combined with a simultaneous differentiation with other genomically and/or symptomatically related viruses. Arch Virol. 1996;141:331-344.

23. Reid S, Ferris N, Hutchings G, De Clercq K, Newman B, Knowles N, Samuel A. Diagnosis of foot-and-mouth disease by RT-PCR: use of phylogenetic data to evaluate primers for the typing of viral RNA in clinical samples. Arch Virol. 2001;146:2421-2434.

24. Lee KN, Nguyen T, Kim SM, Cho IS, Van Quyen D, Khang DD, Park JH. Development of one-step multiplex RT-PCR method for simultaneous detection and differentiation of foot-and-mouth disease virus serotypes $\mathrm{O}, \mathrm{A}$, and Asia circ $\mu$ lating in Vietnam. J. Virol Methods. 2011;175:101-108.

25. Sanson R. The epidemiology of foot-and-mouth disease: implications for New Zealand. New Zealand Vet J. 1994;42:41-53.

26. Blackall R, Gloster J. Forecasting the airborne spread of foot and mouth disease. Weather. 1981;36:162-167. 